\title{
A Business Analysis Perspective for Engineering Education in Egypt
}

\author{
Ashraf Elsafty ${ }^{1}$, Hanaa El Sayad ${ }^{2}$, Ibrahim Shaaban ${ }^{3}$ \\ ${ }^{1}$ ESLSCA Business School - Egypt Branch, Egypt \\ ${ }^{2}$ Faculty of Engineering at Shoubra, 108 Shoubra St. Cairo, Egypt \\ ${ }^{3}$ Civil Engineering and Built Environment, University of West London, UK, Former Dean of the Faculty of Engineering at \\ Shoubra, Egypt \\ Correspondence: Ashraf Elsafty, ESLSCA Business School - Egypt Branch, Egypt.
}

Received: Feb. 17, 2020

Accepted: Mar. 12, 2020 Online Published: Mar. 16, 2020

doi:10.11114/jets.v8i5.4721

URL: https://doi.org/10.11114/jets.v8i5.4721

\begin{abstract}
This work examines engineering education in Egypt provided by state (government funded) universities. There have been concerns from all stakeholders about the graduates' knowledge and skills. The chronic problems with higher education in Egypt in general have been previously reported in the Literature, but this paper provides insights form engineering academics with many years of experience in Egyptian engineering education and a fresh look from a business perspective at the phenomenon. In this manuscript, the institutions are analyzed using the integrated business anatomy model, in order to identify the underlying causes of the problems observed. The structural, operational and environmental (both external and internal) challenges that lead to the current status are clearly detected. The analysis highlighted several constraints that hinder radical reforms. Amongst these constraints is the legal and organizational framework in which the state funded universities operate. Other social, technological and economic factors also play important parts. The recipe for improvement provided by the authors has taken all these elements into consideration. This work hopes to provide focus and direction for future reform efforts.
\end{abstract}

Keywords: higher education, Egypt, engineering education, quality

\section{Introduction}

Each year approximately 35000 fresh engineering graduates join the Egyptian Engineers Syndicate (Deabes, 2015). In 2001, the number of graduates was only 12213 (El-Sayed, Lucena \& Downey, 2006). Therefore, since the turn of the century the number of annual engineering graduates from Egypt has tripled. Rabeae (2017) reported that the governmental universities will admit 17170 students in 2017. Leaving the remainder of those who which to study engineering to be enrolled in private universities or higher education engineering institutes also offering BSc degrees in engineering. There have been concerns about the quality of education these engineers receive and skills acquired during their studies by academics (Riad \& Kamel, 2004), employers (Osman, 2011) and the Syndicate (Elkhatary, 2017). Al-Harthi (2011) even reported that Egyptian undergraduate students are aware that their education is not related to the required employment skills. International organizations have also expressed concern about the skills of Egyptian graduates (Egypt Human Development Report, 2010; OECD-World Bank, 2010; Assaad, Krafft, and Isfahani, 2014; Murata, 2014). A number of conferences and workshops discussed these issues over the years (recent ones were highlighted by El Araby, 2014; Deabes, 2016; and Zein, 2017).

Shann (1992) identified the chronic symptoms of the higher education system in Egypt in general. She noted severe crowding, decline in quality, out dated curriculum, limited educational facilities and resources and reliance on private tutoring. Similar observations were made by Holmes (2008), Schomaker (2015) and Habibi \& El-Hamidi (2016), which shows that even many years later the symptoms were still there. Loveluck (2012) added other perspectives including: over-centralized control, focus on rote learning for examination, inadequate access and funding \& research capacity. Based on these symptoms, recipes for reform have been suggested (OECD-World Bank, 2010). The Ministry of Higher Education has taken notice of these recommendations and established a "Center for Higher Education Reform" in the early 1990's and later another entity was established under the name "Project Management Unit for Educational Development" in 2003. Egypt has received aid to help in the reform efforts from international organizations since the 
late 1980's (World Bank, 1989). Many engineering education development projects have been funded through various initiatives (Abdellah, Taher \&Abdel-Rahman, 2008). However, the concerns for quality still persist (El Hooty, 2018).

\section{Research Significance}

All previous work cited above concentrated on documenting signs of inadequate Egyptian higher education in general and sometimes engineering education in particular. In addition, these studies were mainly conducted by international scholars or organizations. The opinions of Egyptian engineering educators, with many years of experience in government institutions, like the second and third authors, were not documented. So far the reform initiatives have originated from funding provided by international bodies which dictate how the resources should be spent. A complete analysis of government engineering education providers was not previously presented in the manner described in the current paper. This analysis will highlight the underlying causes of the observed symptoms before improvements can be suggested and will help direct future funding and efforts to bring about positive changes in Egyptian engineering education.

\section{Methodology}

Hall, Swart \& Duncan (2012) pointed out that higher education institutions are being transformed into major business enterprises in the new global reality. Krouse (2018) supported this view by stating that higher education institutions: "must think creatively and adapt to meet changing economic and environmental factors and students' expectations. That means more focus on costs and expenditure, just like business. It also means exploring alternate revenue streams and creative finances, just like business". Gekeler (2018) went as far as arguing higher education institutions must distinguish themselves in a saturated market place by renewing the product offerings to their students. Perhaps it is time that higher education providers are studied from a business perspective in order to arrive at a deep understanding of the challenges faced by these entities.

Elsafty (2018) proposed a contextual framework to analyze social study case, as an anatomy model to closely study organizations before attempting to solve any noticeable problems. Whereas addressing a focused research problem is crucial conducting scientific research, as of the consequences on the whole steps reaching conclusion. Researches face difficulties addressing their newly selected problem, especially post-graduate candidates for the first time. Elsafty (2018) introduces a framework of nine elements to enable researches formulate clearly defined and focused problem definition, and a comprehensive framework to analyze the case researched with a comprehensive contextual analysis. Specially within social studies, the framework consolidates all relevant elements in one place acting as 'Anatomy' of context studied.

On the way to contextual analysis of the research, Elsafty (2018) provided a holistic framework to analyze the case using 9 elements covering the whole ecosystem of educational organization(s) and all related stakeholders, including suppliers, distributors, customers, competitors, government agencies, and so on - involved in the delivery of educational outcomes, and related service through both competition and cooperation. Elsafty (2018) framework illustrate the interrelations among all elements affecting the research problem, where each element in the framework affects and is affected by the others, creating a constantly evolving relationships in which each element must be flexible and adaptable in order to survive, as in a biological ecosystems.

Elsafty (2018) nine elements framework, developed used by deploying more than one of the main methodological approaches rooted within research methods. Starting by systematic review of previous literature synthesizing problem definition elements in social studies, then by conducting qualitative meta-analysis, as rigorous review on more than 3000 research methods students using the framework defining an analyzing their own cases. Both systematic review and qualitative meta-analysis helped to develop and to formulate such methodology that generates the nine elements framework targeting a holistic framework to analyze organizational and social related contextual analysis of a research problem.

The nine elements framework has been used in wide range of applications not only research. For professional consultancy, the framework helped diverse types of organizations (industrial, food, service, educational, trade, ... etc.) analyze their problems and properly address it in a comprehensive way to reach proper outcomes for decision making. While in education, the framework supported and used by postgraduates (overall number exceeds $3000+$ student, since 2011 till 2020) to develop their own research projects, thesis and dissertations by formulating a rigorous problem definition and contextual analysis for their researches.

The framework is shown in Figure 1. The authors believe that this new perspective can discover the underlying factors that are causing the problems faced by engineering education in Egypt as the model was shown to be applicable to any type of organization. 


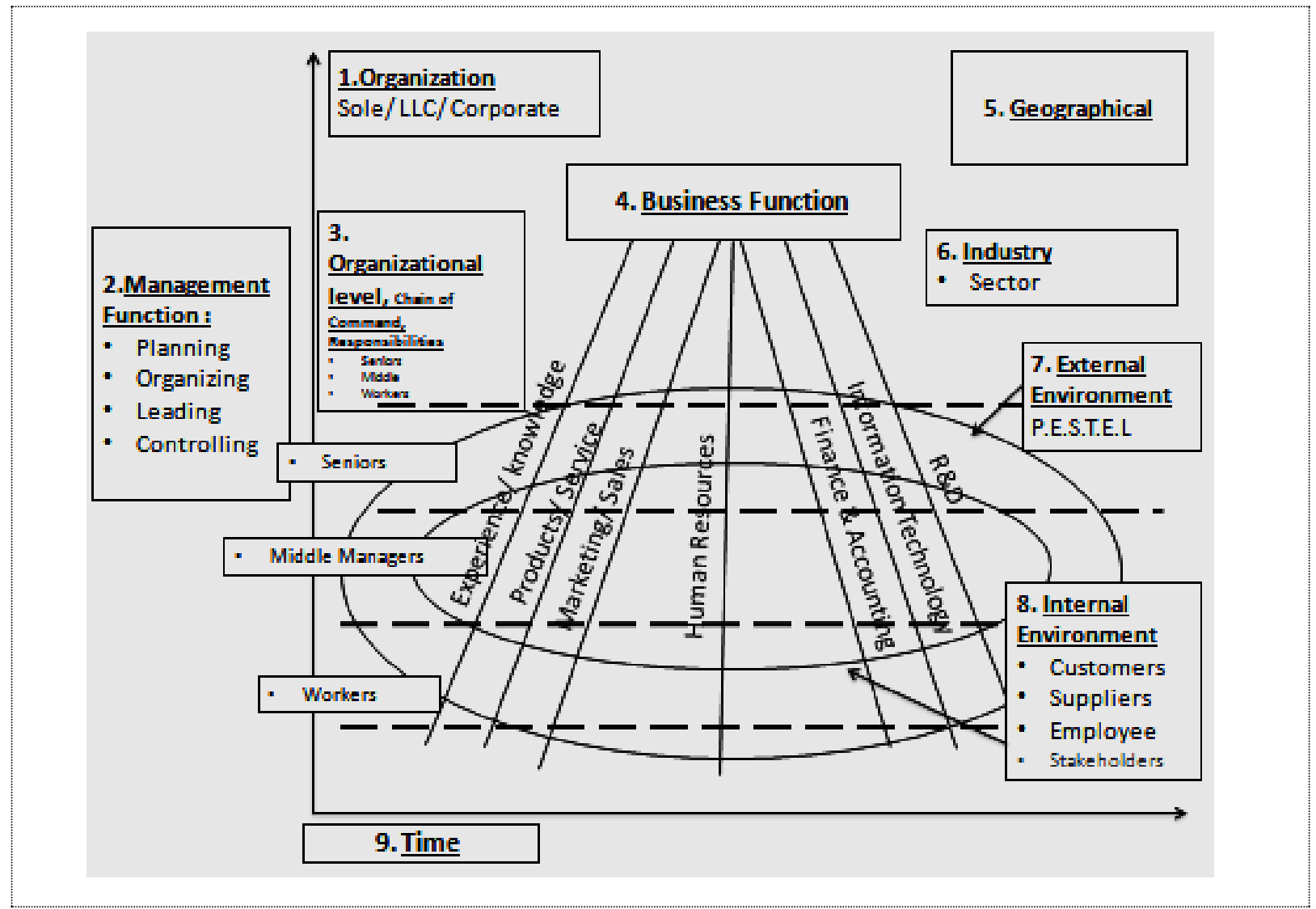

Figure 1. Business Anatomy Model Proposed by Elsafty (2018)

\section{Discussion and Analysis: Business Anatomy for the Government Faculties of Engineering in Egypt}

In the following sections The Egyptian governmental faculties of engineering are examined in accordance to the business anatomy model of Elsafty (2018), shown in Figure 1.

\subsection{Organization (Establishment Process of an Engineering Education Provider)}

Public faculties of engineering are higher education providers operating as part of government funded universities in Egypt. To establish a new faculty, a chapter or decree is added to the "Executive Regulations" of the "Higher Education Law No. 49 issued 1972". The Supreme Council of Universities and Engineering Sector Committee approve the application for a new engineering faculty. Finally, the prime minister of Egypt signs the decree thereby giving permission to its establishment. Before the start of any academic year "Central students Office" allocates a certain number of students to study in each faculty based on their secondary school GPA.

This formal process of establishing new faculties of engineering affect their mission, diversity, modernity and/or limit their ability to offer up to date education. The faculties have no say in the number or academic achievement levels of the admitted students. The faculties also have to approve their curriculums from the Engineering Sector Committee, which has a traditional outline for the courses offered in each department.

The "Higher Education Law No. 49 issued 1972" shapes many aspects of higher education provision in Egypt. It dictates, how to establish a new higher education establishment as seen above, what is the organization structure of higher education establishments, what each unit in the structure does \& how it operates, how to recruit faculty staff members \& compensation, promotion, retirement and reprimand rules, what degree programmes are offered by each establishment...etc., as shall be seen in the next few sections.

\subsection{Management Functions Conducted at Government Faculties of Engineering}

\subsubsection{Planning}

The concept of planning in faculties of engineering has been traditionally associated with tasks such as: asking the University President for money to buy new equipment or construct more buildings; preparing educational schedules: exam time tables, assigning staff for various tasks (e.g. laboratory managers, student mentors ...etc.); deciding the number top graduates to hire each year in each department; dividing students between academic departments, following 
the preparatory year and similar operational plans (approving theses titles and supervisory and examining roles etc...).

The National Authority for Quality Assurance and Accreditation of Education (NAQAAE) was established by the Law No. 82 in 2006, and started operations in 2007. Its' aims were to: develop educational establishments in order to improve the educational process and its outputs using the international standards, gain the trust of society, increase competitiveness regionally and globally, and serve sustainable development in Egypt. The authority is not a regulatory body, but it grants accreditation to educational institutions upon establishing an internal quality assurance system in faculties and after conducting a "Self Study" of each faculty by the team in the quality assurance unit (NAQAAE, 2006).

With NAQAAE on the higher education scene, and as part of the "Self Study" requirements, Faculties of Engineering started to draft so called "Strategic Plans", following the procedures and format used to generate such plans (e.g. Strategic Plan for Shoubra 2012-2017). However, the existence of a document does not mean that it is useful or at least applicable. For example, the Egyptian government finances Shoubra with L.E. $150 \mathrm{M}$ annually, the strategic plan 2012-2017 needed between L.E. 189 - 260 annually for implementation. This had not been granted. Essentially the plan was not implemented. The current status keeps planning in its traditional operational role.

\section{2.2 Organizing}

The organization structure for all faculties not only engineering is dictated by the "Higher Education Law No. 49 issued 1972". The Dean or the faculty council has no power to alter the organization structure. Units or departments are added by changes in the law or after approval from the supreme council of universities. For example, when NAQAAE was established in 2006 clauses were added to the law to create quality assurance units in the faculties.

\subsubsection{Leading}

Deans, vice deans, heads of departments are appointed in accordance with "Higher Education Law No. 49 issued 1972". The president of Egypt signs the decree appointing the dean of each faculty in all universities. Vice deans are appointed by after the University President signs a decree. The leadership style, effectiveness or success depends mainly on individual attributes. There is no formal training for leaders and definitely the selection process does not guarantee choosing the most likely leader to succeed.

\subsubsection{Controlling}

As for monitoring, practically, no performance appraisal system is in place for academic staff. The teaching capability, scientific competence, and cooperation with colleagues are not assessed in any formal way. Student performance is monitored through written or practical examinations.

Controlling academic staff and students is dictated in "Higher Education Law No. 49 issued 1972". The law indicates how staff can be reprimanded. In fact, such proceedings rarely lead to any harsh measures. For students there can be some serious consequences such as temporary or final dismissal or deprivation from sitting an exam.

Theoretically performance appraisal of administrative staff is carried out in accordance with "Civil Government Employees Law No. 47 issued 1978, clause 28”. Practically, however, a document is completed giving each employee more than $95 \%$ of performance score each year. If managers do not do that, employees become extremely unhappy and perhaps hostile, as they will not get the small annual increase in salary, which they depend on to get by.

\subsection{Organizational Levels in Egyptian Engineering Education Providers}

A typical organization structure is shown in Figure 2 for the Faculty of Engineering at Shoubra. It is a complex structure with non academic units each reporting to one of the three vice deans or the "Faculty Administrative Manager". Those four key persons report in turn to the Dean. Quality assurance unit's head and heads of academic departments report to the Dean directly who also manages his own support staff. Again, the structure is dictated by with "Higher Education Law No. 49 issued 1972". Therefore, all faculties of engineering, regardless of their size, have the same structure.

As seen from the structure, the quality assurance unit has no authority over any member in the faculty community. They are in effect just advisors, and academic or administrative staff members have no obligation to comply with any of their recommendations. NAQAAE itself also has no power to alter, for example, any of the outdated teaching practices. Osman (2011) argued that NAQAAE has neither an effective impression nor mandates to improve the performance of universities.Schomaker (2015) found structural shortcomings and implementation problems related to the current accreditation system introduced by NAQAAE.As a result of this situation, the aims of NAQAAE and the quality assurance units within faculties, specifically education development, are difficult to achieve.

The inadequacy of non academic departments adversely impacts academic studies. For example, the laboratory technicians report to the "Faculty Administrative Manager", not the academic head of department that uses the laboratory. It is difficult to get them to cooperate in student learning by conducting educational experiments or keeping 
the equipment well maintained. Bureaucracy causes problems, like when, for example, an apparatus needs to be fixed. This requires many authorizations from budget/ procurement and there is usually a long time lag until things get done.

Student support department overlooks the activities undertaken by student societies. This department keeps these activities running in traditional areas, like theatre, poetry, music, sports ...etc. Sadly, this department, if restructured and given new authority and mandate, can also organize engineering oriented extra-curricular or co-curricular activates that would help in student development and learning.

Unfortunately, department councils and faculty councils have little real powers to improve teaching practices. They cannot force any faculty staff member to change his education style or update the topics discussed in class. The roles of these councils are limited by what is permitted in "Higher Education Law No. 49 issued 1972", which is essentially running academic affairs.

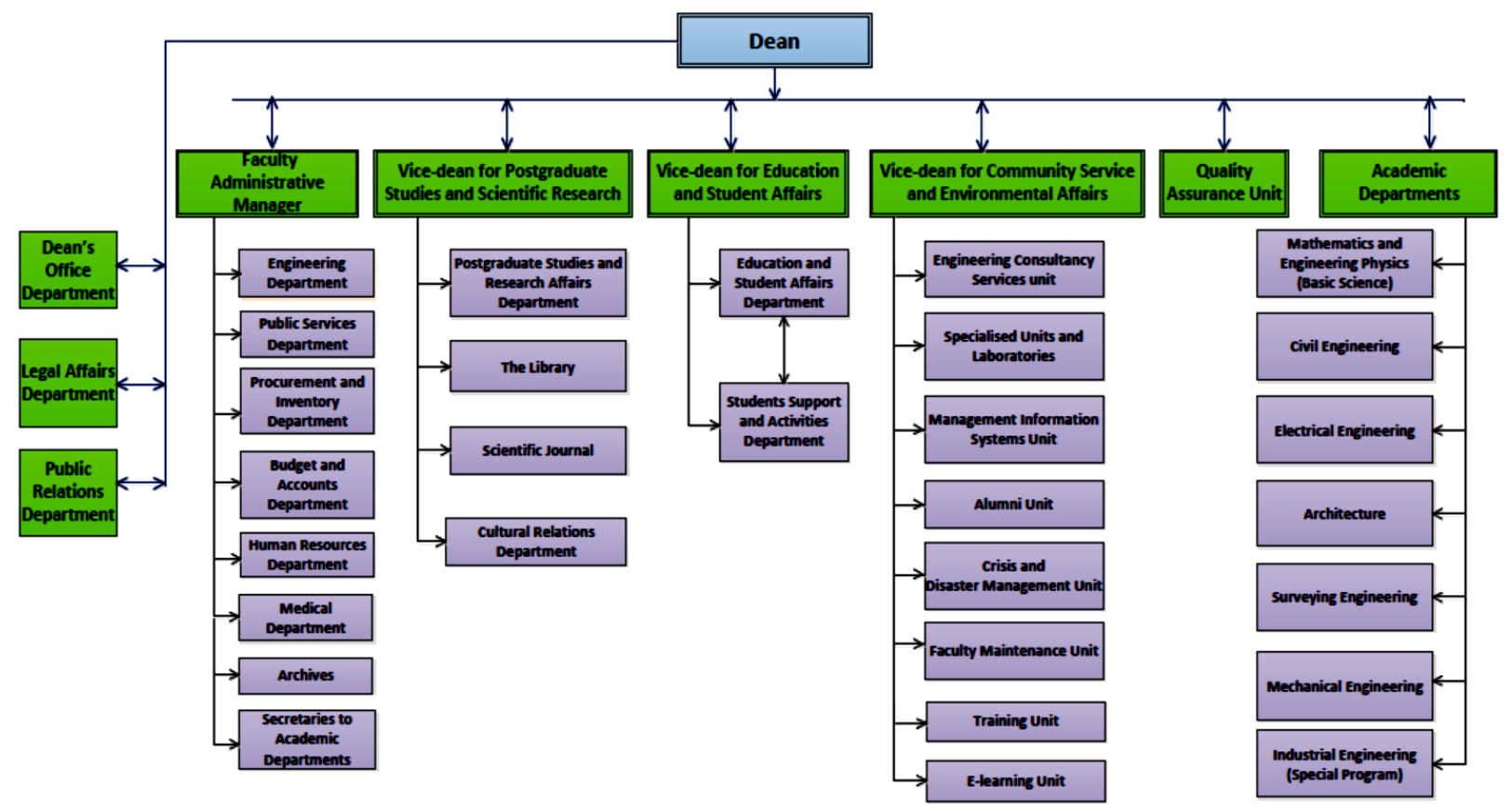

Figure 2. Typical Organization Structure for a Faculty of Engineering in Egypt

\subsection{Business Functions Conducted by Egyptian Engineering Education Providers}

\subsubsection{Experience/ Knowledge of Staff Members}

The academic staff members are appointed in accordance with "Higher Education Law No. 49 issued 1972". The law dictates certain age, qualifications and academic achievement for academic candidates to be appointed. Usually, a number of top graduate performers in an academic department are appointed annually as demonstrators. They work their way through a master and doctorate degrees. At this point they become lecturers and continue carrying out research to be promoted to higher academic positions. Usually, a faculty member graduates from a department and keeps working there for his entire academic career. In the rare event, when there is shortage in a particular specialty, a job advert is placed asking external academics to apply for a vacant position.

Administrative staff members were appointed in accordance with the Civil Government Employees Law No. 47 issued 1978, clause 28which prevails in Egypt. They are usually trained by older personnel on the job. Sometimes they can adversely affect education due to their poor selection, training or motivation. For example, a laboratory assistant may be unable to operate apparatus or the departmental secretary taking too many days off work.

It should be noted that there are limited plans for hiring replacements to any of the administrative staff who retire. Recently in 2016, a replacement of Law 47 was approved under the name Civil Service Law No. 81, which introduced more strict measures on hiring employees. Egypt is seeking to reduce the number of civil servants by $50 \%$ before 2030 (El - Dada, 2017). The new Law No. 81 encourages employees to take up early retirement. It is expected that this trend will worsen the situation in academic institutions.

\subsubsection{Products/Service Provided by the engineering Education Providers}

The graduate is the most important product of the faculties of engineering. Other products include scientific research (Self Study 2013-2014, p. 94) and community services such as providing engineering consultation to the various 
industries (e.g. manufacturing, construction, and telecommunications), (Self Study 2013-2014, p. 61). Scientific research and community service are carried out individually by academic staff members in their own free time or through the relevant consultancy units in the Faculty of Engineering.

\subsubsection{Marketing/Sales Conducted by the Engineering Education Providers}

These business functions do not exist as such. Mark (2013) and other quality assurance literature consider students as customers of the educational establishment. Hartmann (2008) in her working paper on private tutoring in Egypt argued that the students are consumers, private tutors are the suppliers and education is the commodity. However, it is difficult to apply consumer or consumer theories to Egyptian students attending governmental or even private universities. Each year students compete, by trying to get the best GPA in secondary schools, in order to be accepted in one of the governmental or private faculties. The available places in the faculties of engineering are much less than the number that would like to study engineering, whereas in a traditional business setting, firms compete with one another for customers. In addition, in governmental universities, the bench fees paid by students cannot be considered as a fair value for the education provided, regardless of its quality. Moreover, Bunce, Baird \& Jones (2017) found that considering students as customers and treating them as such damages their academic performance, i.e. quality will suffer. The authors consider that students are inputs, and the education process transforms them into graduate products. The assumption is supported by Pereira and Da Silva (2003) as seen in the model in Figure 3.

\begin{tabular}{|l|l|l|l|} 
Input & Process \\
\hline $\begin{array}{l}\text { Students } \\
\text { Faculty and Staff } \\
\text { Funding } \\
\text { Facilities } \\
\text { Goals of the } \\
\text { University }\end{array} \quad$\begin{tabular}{l|l} 
Training all personnel \\
Teaching methods \\
Learning \\
Advising \\
Counselling \\
Tutoring and other means of additional help \\
Evaluations leading to promotion and tenure \\
Paperwork \\
Infrastructure: policies, practices and politics \\
Red Tape
\end{tabular} \\
\hline
\end{tabular}

Figure 3. Model for Engineering Education Process as Proposed by Pereira and Da Silva (2003)

Annual adverts are placed in news papers or on the internet website of the faculty to announce the beginning of admission process for postgraduate degrees, but this cannot be considered as a marketing effort (Self Study 2013-2014, p.99).

Attracting industry clients to benefit from the consultation services offered by the Faculties of Engineering is carried out by individual efforts, not through any organized marketing program (Self Study 2013-2014, p. 61).

\subsubsection{Human Resources Department Role in Engineering Education Providers}

HR functions are split between those for academic and non academic staff. Different laws govern the rules applied to each group of employees. There are in fact separate departments assigned to the activities of each group. In general, HR activities are mainly related to managing time off work, payroll and compensation. No talent acquisition, training, performance appraisal takes place. Academic interviews are rare as academics are usually automatically appointed from the highest scoring graduates in each department (Self Study 2013-2014, p. 90). It is only when PhD holders from outside the university are being recruited that interviews take place. These interviews are conducted by senior academic staff members and no HR employees are involved. With the introduction of quality assurance measures, training workshops were organized through NAQAAE for academic and administrative staff. The workshops were designed and implemented by NAQAAE for all faculties in Egypt and HR departments had no role in identifying or recommending training needs.

\subsubsection{Finance \& Accounting Role in Engineering Education Providers}

The accounting function exists and is strictly carried about in accordance to the law. It is used to calculate the salaries of staff, payoff the purchases, collect bench fees from students, collect money from industrial clients ....etc.

Finance comes from government funding, consultancy services or student bench fees. Government funding cannot be negotiated by the dean, and it usually depends on the number of academic and non academic employees and whether 
there are plans for new infrastructure in the faculty. For example, the annual sum for the faculty of Engineering at Shoubra is L.E. $150 \mathrm{M}$.

Egypt spends $23.4 \%$ of per-captia GDP on higher education. This percentage is low if we compare it with $98.2 \%$ in Jordan, 53\% in Syria, 84\% in Lebanon, 55.8\% in Tunisia and 89.7\% in Morocco (El Araby, 2010). Consultancy services are negotiated with the clients, depending on the size and complexity of the project. There are guidelines in the law that dictate how much to charge students to study in governmental universities, with undergraduate students paying a small flat bench fee, and post graduate students paying per credit hour studied. However, students in private universities do pay high tuition fees. All accounting and finance activities are supervised and audited by the "Accountability State Authority - ElgehazElmarkaziLel-mohasaabat" and the University, (Self Study 2013-2014, p. $53)$.

\subsubsection{Information Technology Status in Engineering Education Providers}

Information technology infrastructure, such as student educational computer laboratories, desk top facilities for administrative staff to carry out day to day tasks, telephones and fax machines, does exist in all faculties of engineering. There is usually an internet service for the dean, vice deans and heads of academic departments. Academic staff members have no desk tops or internet facilities in many faculties of engineering.

\subsubsection{Research \& Development Conducted in Engineering Education Providers}

Scientific research is carried out by academic staff members and postgraduate students, but this is directed towards publishing papers in technical engineering academic journals or conferences. Academic staff should publish a certain number of papers in refereed journals before being promoted to a higher academic degree. Postgraduate students must also write similar publication(s) jointly with their supervisors before they are allowed to defend their theses. Although there are some publications, by Egyptian academics, dealing with quality assurance measures and accreditation criteria in Egypt, the authors cited only 1 publication related to the pedagogic research in engineering education (El Bahrawy, 2005). Moreover, the scientific research conducted in faculties is traditionally not dedicated to developing the management / business functions or the performance of a faculty (Self Study 2013-2014, p. 94-95). One of the main aims of establishing the "Quality Assurance Units" in faculties was to develop the performance of the different departments in order to improve learning outcomes. However, the role of the "Quality Assurance Units" at the moment is only evident in preparing the documents needed for accreditation (Self Study 2013-2014, p. 103-111).

\section{Geographical Distribution of Engineering Higher Education Establishments in Egypt}

All of the 24 governmental universities and most of the 24 private universities have a faculty of engineering. Many of these universities are clustered around Cairo, the capital of Egypt; however, at least one university operates in each of the major governorates. The Faculty of Engineering at Shoubra is located inShoubra Street, Cairo, and is an example of a medium size government faculty in Egypt. It is based on two campuses about $2 \mathrm{Km}$ apart.

The academic departments in government faculties are usually biomedical, civil/structural, mechanical/mechatronic, architectural, electric/electronic, chemical/industrial. Some faculties have unique departments like the Surveying Engineering Department at Shoubra, Aeronautical - Aerospace Engineering Departmentand Mining, Petroleum and Metallurgy Department at Cairo University, Textile Engineering Department at Mansoura and Alexandria Universities, and Nuclear Engineering Department or Marine Engineering and Ship Building Department at Alexandria University. Recently, faculties have started to introduce Renewable Energy departments or programmes like in Shoubra and Aswan Universities. However, there is still room for more specialties to be added to reflect the geographic and demographic diversity of Egypt and to keep up with market demands.

\section{Industry - Higher Education, Funded by the Egyptian Government.}

\section{External Environment in Which Egyptian Engineering Education Operates - P.E.S.T.E.L}

\subsection{Political}

The turbulent political situation in Egypt has negatively affected the staff and students all the higher education system. It is ironic that since January 2011, twelve different higher education ministers have taken office. Some political aspects about higher education in Egypt, have been covered in the Carnegie Paper (Lindsey, 2012).

\subsection{Economic}

Due to the difficult economic situation in Egypt, spending on higher education is very low compared to other countries. The last reported spending was $3.8 \%$ of the GDP. This ranks Egypt at the $110^{\text {th }}$ position globally (UNDP, 2013). In governmental Egyptian higher education, students only pay a token bench fee. Low spending coupled with having no freedom to alter the fees paid by students reduced the income of the faculties of education in governmental universities. Although the private universities are legally non-profit organizations, they charge the students relatively high fees to 
cover costs since fees are the main sources of income for private universities. Internationally, faculties of engineering have more freedom and income opportunities which enable them to provide a reasonable educational service.

\subsection{Social}

Egyptian society has great respect to education and people try their best to get a university degree. The demand for higher education in Egypt is growing and the sector is undergoing considerable change as new private providers joined publicly funded universities (Mourad, Ennew \& Kortam, 2011). However, family income level has redefined the type of students that can study in various places. The poor quality of the state education system, lead to widespread reliance on private tutoring to supplement it (Loveluck, 2012). Those who come from higher income families usually have a better chance of getting higher GPA in secondary schools since they have access to good quality private tuition (Hartmann, 2008; Egypt Human Development Report, 2010; Buckner, 2013).

The effect of family income on the ability to score high GPA in school, is found in a study by the Information and Decision Support Center in 2009, which sampled 4286 students from 6 public and private universities (12 Colleges), and 9 private higher institutes. The results indicated that $47 \%$ of the students who had their high school from private secondary schools joined a public university while only $16.3 \%$ of them went on to private universities. On the other hand, $61.5 \%$ of the students who attended high school in IGCSE or American diploma providing schools joined public universities. Whereas, $3.1 \%$ students coming from the public governmental secondary schools continued their studies in private universities and 35.5\% were in higher institutes, which accept lower secondary GPA (cited in El Gerby, 2012).

Students from upper or high middle income families end up studying at private higher education facilities or faculties like medicine or engineering in well established governmental universities. Middle to lower income families usually prefer that their children study at governmental universities if they were able to achieve secondary school GPA criteria for admission. Those with lower secondary school GPA are forced to join the private universities or private higher institutes. Many students coming from middle to lower income families, will need to work and study at the same time, to be able to pay their the high fees demanded by private higher education establishments. This is the case as $27.8 \%$ of the population were below the poverty line in 2015 (UNDP Human Development Report 2015), and the percentage is expected to be more today. Although, the percentage of students working and studying is unknown, evidence of this phenomenon is cited in the work of Habibi and El-Hamidi (2016), who were quoting the words of a student objecting to the proposal of increasing the bench fees for students attending governmental universities in Egypt.

This social and economic divide, in students attending the various higher education faculties, has definitely affected the educational receptiveness and ultimately success of the poorer individuals attending difficult programs like engineering. El Ansari et al. (2013) examined the physical and psychological health for students at different faculties in Assiut University. Several health indicators were monitored. Students in engineering felt burdened by their study work load and were somewhat stressed compared to other faculties.

\subsection{Technological}

Engineering is the application of technology. Unfortunately, Egypt is not as technologically advanced as it should be. Table 1 shows a comparison of various IT indicators for 3 Middle East countries. The best indicator would be " 1 " and it is clear that Egypt lags behind other countries in the Middle East region. The technological infrastructure falls short of supporting e-learning programs. In addition, many students still do not have access to computer and Internet facilities (Anis, 2011). This situation definitely affects the utilization of technology in learning and hence the quality of graduates.

Table 1. Comparison of IT Indicators for 3 Middle East Countries

\begin{tabular}{l|l|l|l}
\hline Index & Oman & Morocco & Egypt \\
\hline Networked Readiness Index & 52 & 78 & 96 \\
\hline Political and Regulatory Environment & 53 & 70 & 102 \\
\hline Business and Innovation Environment & 58 & 87 & 113 \\
\hline Infrastructure & 46 & 102 & 94 \\
\hline Skills & 76 & 110 & 111 \\
\hline Business Usage & 94 & 105 & 129 \\
\hline Social Impact & 46 & 59 & 103 \\
\hline
\end{tabular}

(Data Source: https://knoema.com/GITR2015/global-information-technology-report-2016) 


\subsection{Environmental}

Egypt has diverse natural and built environments. Sometimes severe rain causes floods in Upper Egypt, Alexandria and Sinai leading to road blockages (Egypt: Flood, Oct 2016). Even without weather problems, ease of transportation to and from the faculties of engineering has a profound effect of the education. Alaa El-Din (2016) noted that: "Although transportation methods may seem affordable, the time spent commuting from one district to another is frequently stressful and time consuming." If staff and students travel are using uncomfortable means or waste a long time to arrive to HEI's, their performance as teachers or learners will be hampered. There are no programs to make educational operations more environment-friendly. Environmental protection laws are directed towards protecting the Nile and safe solid waste disposal ...etc. do exist in Egypt (e.g. Law 4 issued 1994). Sound and air pollution affects all people in large cities, and this has an impact on all aspects of life, not only education.

7.6 Legal

The law that governs higher education in Egypt is "Higher Education Law No. 49 issued 1972". The legal aspects of the higher education system in Egypt are described in the Tempus (2012) report. This law has affected the education quality in a profound way, as it dictates every aspect in higher education establishments. Amendments to this law has been numerous, but has always served a certain political agenda.

\section{Internal Environment Conditions in Egyptian Engineering Higher Education Establishments}

\subsection{Customers}

Students cannot be considered as customers as discussed above. Clients for engineering consultations or those who attend training workshops offered by the faculty may be considered as clients. Usually those clients accept the services offered by the faculty in exchange for fees. The faculties do not conduct market research to determine which services are needed by local clients.

\subsection{Suppliers}

The Supreme Council of Egyptian Universities and Ministry of Higher Education annually decide the number of students admitted to study in each of the Faculties of Engineering. A faculty cannot refuse any student allocated by the council and Ministry. In Shoubra, there are 5004 undergraduate and 611 postgraduate students enrolled at various departments/programmes (Self Study 2013-2014, p.11 \& 21). They are the inputs for the educational operations carried out at the Faculties of Engineering. In any operation, the quality of the inputs affects the quality of the output.

\subsection{Employee}

Academic and non academic staff work at Faculties of Engineering as discussed above, with rules and guidelines in accordance to the law. For the Faculty of Engineering in Shoubra, the total number of academic staff is 664, while the support staff is 324 (Self Study 2013-2014, p. 12-14), including those on leave. Other Faculties of Engineering may have higher or lower numbers depending on the governorate where it is located or how long has the faculty been established.

\subsection{Stakeholders}

All members of the society are stakeholders in the engineering education process because engineering affects every aspect of life. Parents, academic staff, administrative staff, undergraduate and postgraduate students, worldwide researchers, local and international engineering firms or industrial facilities, government sectors, Egyptian and overseas employers are examples of stakeholders. The second part of this series of papers is dedicated to considering the views of stakeholders on the current gaps in Egyptian engineering education and what needs to be done to improve it.

\section{Time}

El-Sayed, Lucena\& Downey (2006) gave an account of the history of engineering education. Miyakoshi (2016) pointed out that the free tuition policy introduced by president Nasser in the 1960's lead to: "the large student enrolment in Egypt today, resulting in a high student-professor ratio imbalance, a too heavy teaching load for professors, a deficiency of professors' support for students, and too little time for professors to improve their own ability. In addition, there is little scope for updating programmes and courses and improving infrastructure. The out-of-date programs are increasing the gap between the graduates' skills and the technical and other skills required by industry and society at large". El-Sayed (2004) expressed hope that the Egyptian Engineering community will live up to the challenge of the demanding job market and the ever increasing international competition.

\section{Findings and the Way Forward}

Looking at Egyptian Engineering Education Establishments from a business perspective has shown why there are so many chronic problems that were not solved despite the rigorous efforts of reform. It was demonstrated that there are 
organizational, legal, social, technological and various other constraints in place that hinder radical reforms. The authors have conducted a comprehensive review into the practices followed by engineering education providers worldwide (Elsafty, El Sayad, and Shaaban, 2020). This review lead to several recommendations on how engineering education in Egypt can be improved within the constraints highlighted from the analysis provided in current paper.

\section{Conclusions}

1. The application of the Business Anatomy Model proposed by Elsafty (2018) highlighted the underlying causes of the observed problems in the faculties of engineering.

2. The way faculties of engineering are established and structured produce rigid institutions inherently unable to change.

3. The statuary laws have dictated the style of management functions leaving little room for maneuver by leaders. Inefficient management functions indirectly affect the education of students, and definitely affect the moral of all faculty community.

4. The business functions are not conducted as such at the faculties of engineering in Egypt, because of the nature and constraints placed on the faculty. Faculties are not stand alone independent entities; they are orbiting the university and Ministry of Higher Education space and are not allowed to break free. In addition, the employees in faculties are not business oriented.

5. External and internal environments pose many threats to the education quality. However, many of these factors are totally out of the control of the faculties of engineering and cannot be altered in the near future.

6. Any recipe for reform to improve Egyptian engineering education must take into account all the identified constraints to be applicable. The authors made suggestions in another publication.

\section{References}

Abdellah, G. A., Taher, S. E. M. F., \& Abdel-Rahman, M. (2008). Recent developments in Egyptian engineering education through competitive projects. National Committee Meeting, end of term of HEEPF Phase 7, 27 Dec., 2008. Available

at http://www.heepf.org.eg/pdf/research/Recent\%20Developments\%20in\%20Egyptian\%20Engineering\%20Educatio n\%20Through\%20Competitive\%20Projects.pdf

Al-Harthi, H. K. (2011). University student perceptions of the relationship between university education and the labour market in Egypt and Oman. Prospects, 41, 535-551. https://doi.org/10.1007/s11125-011-9216-4

Anis, H. (2011). E-learning in engineering education -General challenges and the Egyptian experience. Available at http://usir.salford.ac.uk/16997/

Assaad, R., Krafft, C., \& Salehi-Isfahani, D. (2014). Does the type of higher education affect labor market outcomes? A comparison of Egypt and Jordan, Economic Research Forum Working paper No. 826. Available at https://erf.org.eg/wp-content/uploads/2014/07/826.pdf

Buckner, E. (2013). Access to higher education in Egypt: Examining trends by university sector. Comparative Education Review, 57(3), 527-552. https://doi.org/10.1086/670665

Bunce, L. Baird, A., \& Jones, S. E. (2017). The student-as-consumer approach in higher education and its effects on academic performance. Studies in Higher Education, 42(11), 1958-1978, https://doi.org/10.1080/03075079.2015.1127908

Civil Government Employees Law No. 47 issued 1978. Available at https://www.minia.edu.eg/spedu/images/gawdaaa/edary/7_law.pdf

Civil Service Law $\quad$ No. $81 \quad$ issued $2016 . \quad$ Available $\quad$ at http://www.benisuef.gov.eg/New_Portal/services/Civil\%20Service\%20Law.aspx (in Arabic)

Egypt Human Development Report 2010-Youth in Egypt: Building our Future, United Nations Development Programme, and the Institute of National Planning, Egypt, ISBN: 977-5023-12-2, Retrieved from http://hdr.undp.org/en/content/2010-egypt-human-development-report-youth-egypt

El Ansari, W., Labeeb, S., Moseley, L., Kotb, S., \& El-Houfy, A. (2013). Physical and psychological well-being of university students: Survey of 11 faculties in Egypt. International Journal of Preventive Medicine, 4(3), 293-310. Retrieved from https://www.ncbi.nlm.nih.gov/pmc/articles/PMC3634168/

El Araby, A. (2010). Chapter 1: Comparative assessment of higher education financing in six Arab Countries. In A. Galal and T. Kanaan (Eds.), Financing higher education in Arab countries, p 3, ERF Policy Research Report. 
Economic Research Forum, PRR No. 34, July 2010. Dokki, Cairo. https://doi.org/10.1007/s11125-011-9185-7

El Bahrawy, A. N. (2005). The use of computers through a systematic approach to develop engineering education in the area of water resources. Paper presented at the $5^{\text {th }}$ Arab Conference - Systematic Approach in Teaching and Learning, Cairo, April 2005, 286-297. Retrieved from https://search.mandumah.com/Record/31315

El Gerby, S. (2012). Assessing the socio-economic characteristics of higher education subsidies'beneficiaries in Egypt: Problem of subsidizing the rich. MA thesis Submitted to the Economics Department, American University in Cairo. Available at http://dar.aucegypt.edu/bitstream/handle/10526/3601/Thesis.pdf?sequence=1

El Sayed, O. L. (2004) Engineering and Engineering Education in Egypt. Proceedings of the 2004 American Society for Engineering Education Annual Conference \& Exposition. American Society for Engineering. Session 0560.

El Sayed, O. L., Lucena, J., \& Downey, G. (2006). Engineering and engineering education in Egypt, IEEE TECHNOLOGY AND SOCIETY MAGAZINE, summer 2006, 18-25. https://doi.org/10.1109/MTAS.2006.1649024

Elsafty, A. (2018). Business Anatomy Model. Business research methods lectures. Fall Semester, Paris Eslsca Business School - Mohandessien Branch, Egypt.

Elsafty, A., El Sayad, H., \& Shaaban, I. G. (2020). Educating Engineering Students in Egypt: Recommendations for Improvement. International Journal of Higher Education (IJHE), 9(3), 1-14. https://doi.org/10.5430/ijhe.v9n3p1

Global Information Technology Report https://knoema.com/GITR2015/global-information-technology-report-2016

(2016)

Habibi, N., \& El-Hamidi, F. (2016). Why Are Egyptian Youth Burning Their University Diplomas? The Over Education Crisis in Egypt. Middle East Brief, Brandeis University, Crown Center for Middle East Studies (102), September 2016. https://doi.org/10.2139/ssrn.3054086

Hall. C., Swart, W., \& Duncan, S. (2012). Balancing customer needs and standards in higher education, Quality $\begin{array}{lllll}\text { Approaches in } & \text { Higher } & \text { Education, }\end{array}$ http://asq.org/edu/2014/03/customer-satisfaction-and-value/balancing-customers-needs-and-standards-in-higher-ed ucation.pdf

Hartmann, S. (2008). The informal market of education in Egypt. Private tutoring and its implications. Arbeitspapiere / Working Papers, (88), Department of Anthropology and African Studies, Institutfür Ethnologie und Afrikastudien, Johannes Gutenberg-Universität, Germany. https://publications.ub.uni-mainz.de/opus/volltexte/2008/1618/pdf/1618.pdf

Higher Education Law No. $49 \quad$ issued $1972, \quad$ Available http://www.du.edu.eg/files/\%D9\%82\%D8\%A7\%D9\%86\%D9\%88\%D9\%86\%20\%D8\%AA\%D9\%86\%D8\%B8\% D9\%8A\%D9\%85\%20\%D8\%A7\%D9\%84\%D8\%AC\%D8\%A7\%D9\%85\%D8\%B9\%D8\%A7\%D8\%AA\%20\%D8 \%A7\%D9\%84\%D9\%85\%D8\%B5\%D8\%B1\%D9\%8A\%D8\%A9.pdf (in Arabic)

Holmes, M. T. E. (2008). Higher education reform in Egypt: preparing graduates for Egypt's changing political economy. Education, Business and Society: Contemporary Middle Eastern Issues, 1(3), 175-185. https://doi.org/10.1108/17537980810909797

Law 4 issued 1994 for the protection of the Nile and water ways from pollution, Available at https://www.mwri.gov.eg/index.php/ministry/ministry-17/12-1985 (in Arabic)

Law No. 82 issued 2006 to establish The National Authority for Quality Assurance and Accreditation of Education (NAQAAE). Available at http://qadaya.net/?p=5373 (in Arabic)

Loveluck, L. (2012). Education in Egypt: Key challenges. Available at https://www.chathamhouse.org/sites/files/chathamhouse/public/Research/Middle\%20East/0312egyptedu_backgrou nd.pdf

Mark, E. (2013). Student satisfaction and the customer focus in higher education. Journal of Higher Education Policy and Management, 35(1), 2-10. https://doi.org/10.1080/1360080X.2012.727703

Miyakoshi, M. (2016) Higher Education and Development in Egypt -Exploratory case study of the perception of E-JUST students and graduates. Master thesis in Sustainable Development 325 ExamensarbeteiHållbarutveckling, Department of Earth Sciences, Uppsala University, Sweden.

Mourad, M., Ennew, C., \& Kortam, W. (2011) Brand equity in higher education. Marketing Intelligence \& Planning, 29 (4), 403-420. https://doi.org/10.1108/02634501111138563 
Murata, A. (2014). Designing youth employment policies in Egypt. Global Economy \& Development Working Paper 68, January 2014. Available at: https://www.brookings.edu/research/designing-youth-employment-policies-in-egypt/

NAQAAE (2006). http://naqaae.eg/

OECD-World Bank (2010). Reviews of National Policies for Education Higher Education in Egypt, ISBN 978-92-64-08434-6 (PDF), DOI 10.1787/9789264084346-en, Available at http://siteresources.worldbank.org/INTEGYPT/Resources/REPORTHigherEducationinEgypt-2010FINAL-ENGLI SH.pdf

Osman, W. D. (2011). Higher education in Egypt and needed employability skills in the domestic labor market: Case study from Ain Shams University, Faculty of engineering. Thesis submitted in partial fulfillment of the requirements for the degree of Master of Public Policy and Administration, School of Global Affairs and Public Policy, American University in Cairo. Available at http://dar.aucegypt.edu/bitstream/handle/10526/2807/Thesis_Wafaa_2011.pdf?sequence=1

Pereira, M. A. C., \& Da Silva, M. T. (2003) A key question for higher education: Who is the customer?Proceedings of the $31^{\text {st }}$ Annual Conference of the Production and Operations Management Society, POM-2003, April, 4-7, 2003, Atlanta, GE. Available at https://pomsmeetings.org/ConfProceedings/001/Papers/SOM-19.3.pdf

Riad, S. M., \& Kamel, M. (2004) Engineering education in Egypt: Survey and assessment, Proceedings of the 2004 American Society for Engineering Education Annual Conference \&Exposition, American Society for Engineering. Available at https://peer.asee.org/engineering-education-in-egypt-survey-and-assessment.pdf

Schomaker, R. (2015) Accreditation and quality assurance in the Egyptian higher education System. Quality Assurance in Education, 23(2), 149-165, https://doi.org/10.1108/QAE-08-2013-0034

Self Study 2013-2014 Faculty of Engineering at Shoubra. Available at http://www.feng.bu.edu.eg/feng/images/2014/sera.pdf (in Arabic)

Shann, M. H. (1992). The reform of higher education in Egypt. Higher Education, 24, 225-246. https://doi.org/10.1007/BF00129443

Strategic Plan 2012-2017: Faculty of Engineering at Shoubra. Available at http://feng.bu.edu.eg/images/2014/2012-2017.pdf (in Arabic)

UNDP. Expenditure on education: public (2013) Available at http://hdr.undp.org/en/content/expenditure-education-public-gdp

UNDP. Human Development Report http://www.eg.undp.org/content/egypt/en/home/countryinfo.html

Available

at

World Bank. (1989). Egypt-Engineering and Technical Education Project. Washington, DC: World Bank.http://documents.worldbank.org/curated/en/241081468025736148/Egypt-Engineering-and-Technical-Educati on-Project

Lindsey, U. (2012, September). Freedom and reform at Egypt's universities. The Carnegie Papers, Available at http://carnegieendowment.org/files/egyptian_universities.pdf

El Araby, W. (2014, April 12). Workshop recommends unified admission requirements for faculties of engineering. Elgornal.net, Retrieved from http://elgornal.net/news/news.aspx?id=4537205

Deabes, A. (2015, March 11). Syndicate of Engineers: we receive 35000 graduates annually, we are considering not recognizing 48 higher institutes. Youm7, Retrieved from http://www.youm7.com/story/2015/3/11/\%D9\%86\%D9\%82\%D8\%A7\%D8\%A8\%D8\%A9-\%D8\%A7\%D9\%84\% D9\%85\%D9\%87\%D9\%86\%D8\%AF\%D8\%B3\%D9\%8A\%D9\%86-\%D9\%86\%D8\%B3\%D8\%AA\%D9\%82\%D8 \%A8\%D9\%84-35-\%D8\%A3\%D9\%84\%D9\%81-\%D8\%AE\%D8\%B1\%D9\%8A\%D8\%AC-\%D8\%B3\%D9\%86\% D9\%88\%D9\%8A\%D8\%A7-\%D9\%88\%D9\%86\%D8\%AF\%D8\%B1\%D8\%B3-\%D8\%B9\%D8\%AF\%D9\%85-\%D 8\%A7\%D9\%84\%D8\%A7\%D8\%B9\%D8\%AA\%D8\%B1\%D8\%A7\%D9\%81/2100570 (in Arabic)

Alaa El-Din, M. (2016, March 13). From taxis to tuk-tuks: Cairo's most popular modes of transportation. Ahramonline, Retrieved from http://english.ahram.org.eg/NewsContentP/1/190561/Egypt/From-taxis-to-tuktuks-Cairos-most-popular-modes-of. aspx

Egypt: Floods - Oct 2016, Reliefweb, Retrieved from https://reliefweb.int/disaster/fl-2016-000114-egy

Deabes, A. (2016, November 21). Federation of Arab Engineers' conference to improve engineering education via 
linking it to employment market. Youm7, from http://www.youm7.com/story/2016/11/21/\%D8\%A7\%D9\%86\%D8\%B9\%D9\%82\%D8\%A7\%D8\%AF-\%D9\%85\% D8\%A4\%D8\%AA\%D9\%85\%D8\%B1-\%D8\%A7\%D8\%AA\%D8\%AD\%D8\%A7\%D8\%AF-\%D8\%A7\%D9\%84\% D9\%85\%D9\%87\%D9\%86\%D8\%AF\%D8\%B3\%D9\%8A\%D9\%86-\%D8\%A7\%D9\%84\%D8\%B9\%D8\%B1\%D8 \%A8-\%D9\%84\%D8\%A5\%D8\%B5\%D9\%84\%D8\%A7\%D8\%AD-\%D8\%A7\%D9\%84\%D8\%AA\%D8\%B9\%D9 \%84\%D9\%8A\%D9\%85-\%D8\%A7\%D9\%84\%D9\%87\%D9\%86\%D8\%AF\%D8\%B3\%D9\%89-0D9\%88\%D8\%B $1 \% \mathrm{D} 8 \% \mathrm{~A} 8 \% \mathrm{D} 8 \% \mathrm{~B} 7 \% \mathrm{D} 9 \% 87-0 \mathrm{D} 8 \% \mathrm{~A} 8 \% \mathrm{D} 8 \% \mathrm{~B} 3 \% \mathrm{D} 9 \% 88 \% \mathrm{D} 9 \% 82 / 2976235$ (in Arabic)

El Dada, M. (2017, July 6). Early retirement is the government's tool to reduce the number of civil servants. El-Watan News. Retrieved from http://www.elwatannews.com/news/details/2289263 (in Arabic)

Rabeae, W. (2017, July 15). The number of students to be admitted in governmental universities. Youm7, Retrieved from http://www.youm7.com/story/2017/7/15/\%D9\%86\%D9\%86\%D8\%B4\%D8\%B1-\%D8\%A7\%D9\%84\%D8\%A3\% D8\%B9\%D8\%AF\%D8\%A7\%D8\%AF-\%D8\%A7\%D9\%84\%D9\%85\%D9\%82\%D8\%B1\%D8\%B1-\%D9\%82\%D8 \%A8\%D9\%88\%D9\%84\%D9\%87\%D8\%A7-\%D9\%85\%D9\%86-\%D8\%B7\%D9\%84\%D8\%A7\%D8\%A8-\%D8\% A7\%D9\%84\%D8\%AB\%D8\%A7\%D9\%86\%D9\%88\%D9\%8A\%D8\%A9-\%D8\%A7\%D9\%84\%D8\%B9\%D8\%A7 \%D9\%85\%D8\%A9-\%D8\%A8\%D8\%A7\%D9\%84\%D8\%AC\%D8\%A7\%D9\%85\%D8\%B9\%D8\%A7\%D8\%AA$\% \mathrm{D} 8 \% \mathrm{~A} 7 \% \mathrm{D} 9 \% 84 \% \mathrm{D} 8 \% \mathrm{AD} \% \mathrm{D} \% \% 83 \% \mathrm{D} 9 \% 88 \% \mathrm{D} 9 \% 85 \% \mathrm{D} \% \% 8 \mathrm{~A} \% \mathrm{D} 8 \% \mathrm{~A} 9 / 3325875$. (in Arabic)

El Khatary, M. (2017, October 8). Elnabarawy: Engineering education is in a crisis and the decisions of the syndicate made parents angry. El-Watan News. Retrieved from https://www.elwatannews.com/news/details/2592006 (in Arabic)

Zein, M. (2017, October 26). Next Sunday the ministers of education, planning and military production will start the conference on the future of engineering and technical education in Egypt, Akhbar El Youm. Retrieved from http://akhbarelyom.com/news/newdetails/2557477/1/\%D8\%A7\%D9\%84\%D8\%A3\%D8\%AD\%D8\%AF..- $\%$ D9\%8 8\%D8\%B2\%D8\%B1\%D8\%A7\%D8\%A1-\%D8\%A7\%D9\%84\%D8\%AA\%D8\%B9\%D9\%84\%D9\%8A\%D9\%85\%D9\%88\%D8\%A7\%D9\%84\%D8\%AA\%D8\%AE\%D8\%B7\%D9\%8A\%D8\%B7-\%D9\%88\%D8\%A7\%D9\%84\% D8\%A5\%D9\%86\%D8\%AA\%D8\%A7\%D8\%AC-\%D8\%A7\%D9\%84\%D8\%AD\%D8\%B1\%D8\%A8\%D9\%8A-\% D9\%8A\%D9\%81\%D8\%AA\%D8\%AA\%D8\%AD\%D9\%88\%D9\%86-.html

Gekeler, L. (2018, March 12). Innovation in the Business of Higher Education, Educausereview, Retrieved from https://er.educause.edu/articles/2018/3/innovation-in-the-business-of-higher-education

El Hooty, H. (2018, March 19). Engineers Syndicate Head: Engineering Education is suffering problems and the curriculum is as it was 30 years ago. Youm7, Retrieved from https://www.youm7.com/story/2018/3/19/\%D9\%86\%D9\%82\%D9\%8A\%D8\%A8-\%D8\%A7\%D9\%84\%D9\%85\% D9\%87\%D9\%86\%D8\%AF\%D8\%B3\%D9\%8A\%D9\%86-\%D8\%A7\%D9\%84\%D8\%AA\%D8\%B9\%D9\%84\%D9 \%8A\%D9\%85-\%D8\%A7\%D9\%84\%D9\%87\%D9\%86\%D8\%AF\%D8\%B3\%D9\%89-\%D9\%8A\%D8\%B9\%D8\% A7\%D9\%86\%D9\%89-\%D9\%85\%D9\%86-\%D9\%85\%D8\%B4\%D8\%A7\%D9\%83\%D9\%84-0D9\%88\%D9\%85 \%D9\%86\%D8\%A7\%D9\%87\%D8\%AC-\%D8\%A7\%D9\%84\%D9\%83\%D9\%84\%D9\%8A\%D8\%A7\%D8\%AA-\% D8\%AB $\%$ D8\%A7\%D8\%A8\%D8\%AA\%D8\%A9/3703363 (in Arabic)

Krouse, J. (2018, May 22). Higher Education Is A Business - Is That So Bad?, D!gitalist, Retrieved from https://www.digitalistmag.com/digital-economy/2018/05/22/higher-education-is-business-is-that-so-bad-06167601

Tempus (2012). Higher Education in Egypt. Retrieved on October, $10^{\text {th }} 2017$ fromhttp://eacea.ec.europa.eu/tempus/participating_countries/overview/egypt_tempus_country_fiche_final.pdf

\section{Copyrights}

Copyright for this article is retained by the author(s), with first publication rights granted to the journal.

This is an open-access article distributed under the terms and conditions of the Creative Commons Attribution license which permits unrestricted use, distribution, and reproduction in any medium, provided the original work is properly cited. 